\title{
THE APPROPIATE CAUSATION OF INTENTIONAL BASIC ACTIONS
}

DAVID PEARS

Oxford University

In this paper I shall examine the intersection of two problems. One is concerned with the causation of intentional actions. Given that such an action must be caused by a desire and a belief, suitably related both to it and to one another, must it be caused by them in a particular way, and, if so, in what way? The other is a problem about basic actions. Must a basic action be performed intentionally? I shall investigate the intersection of these two problems. I want to find out how, if at all, the causal route from desire and belief to intentional basic action is restricted. But before $I$ start that inquiry I need to look at each of the two problems separately. It is especially necessary to look at the first one, which is concerned with the connection between an action's being basic and its being intentional. For the term "basic action" is a term of art, and, as the discussions of the last decade have shown, a slippery one.

The nature of these two problems and their intersection may be indicated in a preliminary way by three examples taken or adapted from recent publications.

Suppose that a gunman is out to get his enemy. He finds him, fires at him, but misses. However, the noise of the gunshot causes his victim to die of a heart attack. Did he kill him intentionally, or was the causal route from the constellation of desire and belief to the death too inappropriate? This is a typical example of a class that raises the first of the two problems.

The second problem, about the connection between an ac- 
tion's being basic and its being intentional, may be illustrated by the following example. An experienced typist types the letter $S$ with the second finger of his left hand. Is his basic action typing the letter $S$, or is it making a certain movement with the second finger of his left hand? This poses a well known dilemma in the theory of basic action. If we say that his basic action was typing the letter $\mathrm{S}$, we shall be allowing the description of a basic action to refer essentially to something outside the agent's body, viz. a typewriter; and this goes against the intuition that basic actions must be bodily movements described purely physiologically, or, to be more precise, purely attitudinally. But if we insist that the typist's basic action must be described in this very restricted way, there is a risk that it may not have been performed intentionally. For he may not have known which finger he was using, and this lack of knowledge seems to be sufficient to establish that he did not make the bodily movement intentionally under its purely attitudinal description. Ought we then to allow that some basic actions are not done intentional. ly? If we did take this line, it evidently would not follow that they are done unintentionally. But we would be going against another intuition, according to which all basic actions are done intentionally. This intuition is built into the theories of basic action developed by Danto, Chisholm and Goldman, ${ }^{1}$ and it is a reasonable conjecture that it would be built into Aristotle's theory, if Aristotle returned to take part in this controversy.

As an illustration of the intersection of the two problems, consider the following example. A resentful servant of the kind described by Freud in 'The Psychopathology of Everyday Life' is carrying an expensive vase. He believes that it will break if he drops it on the tiled floor, and he wants to break it. This constellation of a desire and a belief makes

\footnotetext{
1 A. Danto: "Basic Actions", American Philosophical Quarterly (II) 1965, R. Chisholm: "Some Puzzles about Agency" in The Logical WVay of Doing Things ed. K. Lambert, Yale, 1969. A. Goldman: "A Theory of Human Agency" Prentice-Hall, 1970.
} 
him nervous, his nervousness makes him drop the vase, and the impact makes it break. Did he break it intentionally? There is a strong case for a negative answer. For though the causation of the desired result starts from a suitable constellation of desire and belief, its route to the relaxation of the servant's grip is not an appropriate route for intentional basic action.

So much by way of introduction of my topic.

Before I begin to discuss it, there are two likely objections to my programme. First, there may be dissent from my assumption that an intentional action must be caused by a suitable constellation of desire and belief. Second, it may seem unnecessary to take on the task of analyzing the concept of "a basic action". Why not simply tackle the problem of inappropriate causation without any load of theoretical apparatus?

I have no time to answer the first objection by defending my assumption that an intentional action must be caused by a suitable constellation of desire and belief. It would, for example, take too long to make a case against the so-called "logical connection argument", which has often been put forward against this assumption. But there is a conciliatory point which I can make. I am not assuming that the concept of "intentional action" can be analyzed causally: I am assuming only that there is an important causal element in its analysis. For I shall not attempt to give a causal analysis of the concepts of "match" and "mismatch", which are essential ingredients in the mixture. Still, my assumption is a substantial one, and, if anyone dissents from it, I can only hope that what I am going to say about appropriate and inappropriate causation will be translatable into the terminology of his preferred theory.

As for the second objection to my programme, it would indeed be nice to avoid the tangled problems of basic action. But unfortunately I cannot quite do that. For my aim is to explore the difference between appropriate and inappropriate 
causation in what might be called "the vestibule of agency". I am concerned with the causal links which lead up to and include the bodily movement, attitudinally described, but do not go beyond it. But these are causal links in the production of the most favoured candidates for the title "basic actions". Now this does not involve me in all the details of the theory of basic action. But there is one question that I cannot avoid, and that is the question about the connection between an action's being basic and its being intentional.

The reason why I cannot avoid this question will be clear. Outside the vestibule of agency inappropriate causation of a desired result will often show up as a mismatch between what actually happens and the agent's intention: for example, the gunman intended to stop his enemy's heart with a bullet and not with a noise. But within the vestibule of agency inappropriate causation will not show up in the same way, because an intention to make a bodily movement, attitudinally described, is not formulated in a way that specifies the causal links leading up to that movement. Yet the case of the nervous servant seems to violate some requirement of appropriateness in the causation within the vestibule. Are we then to say that he has a general intention about what happens in the vestibule, $v i z$. the intention to produce whatever causal links will lead to the bodily movement, attitudinally described? Or ought we to define appropriateness and inappropriateness of causation within the vestibule in a way that makes no reference to match and mismatch with the agent's intention? These questions force me to take up the problem about the connection between an action's being basic and its being intentional.

So I shall start with this problem.

First, I should sketch the way in which the theory of basic action has developed. Danto's original definition ${ }^{2}$ was this:

2 Loc. cit. 
An agent performs a basic action $A$ when and only when there is no event $\alpha$ distinct from $\mathrm{A}$, which both stands to $\mathrm{A}$ as cause to effect and is an action performed by that agent.

But, as his critics ${ }^{3}$ pointed out, there are at least three things wrong with this definition. First it is too much to stipulate that the basic action $\mathrm{A}$ must not be caused by any other action $\alpha$ done by the same agent. For I may put my razor on a high shelf on Monday and so cause myself to reach for it on Tuesday, but the movement that I make when I reach for it with my right hand will still be a basic action. Danto ought to have said that it would not have been a basic action if it had been caused by another action of mine in the same sequence. Thus it would not have been a basic action if I had used my left hand to lift my right arm up towards the shelf. Second, if I do this, what is caused is the movement, which is not itself an action, but becomes a component of a non-basic action through being caused in this way. Third, though the relation between the action $\alpha$ and the movement A which deprives A of basic status may be causation, it need not be causation. A member of an audience who wants to ask a question puts up his hand, but this movement does not cause a distinct event which is a signal: rather, it counts by convention as a signal. A certain stretching of the lips does not cause a distinct event which is a smile: rather, it is in the nature of things a smile. So Danto's account of the relation between $\mathrm{A}$ and $\alpha$ needs to be generalized to cover such cases.

I shall take the necessary amendments as made, without going through them in detail, because I do not want to delay discussion of the dilemma, which is my main concern in this area. For the same reason I shall say nothing about the much debated question, how the word "action" should be used as a count-noun. It makes no difference to my cluster of problems whether someone who pushes a button performs two actions or a single action satisfying two descriptions.

3 M. Brand "Danto on Basic Actions" Noûs (II) 1968. F. Stoutland: "Basic Actions and Causality" Journal of Philosophy LXV, 1968. J. Margolis: "Danto on Basic Actions" Inquiry XIII 1970. A. Goldman. loc. cit., p. 24. 
Goldman sets up the dilemma about the experienced typist in his book (p. 68). Since he takes the view that all basic actions are intentional (p. 63), he is forced to the conclusion that the typist's basic action is not making the movement with the second finger of his left hand but typing the letter $\mathrm{S}$, which involves the typewriter.

It should be noted that the reason why we cannot say that the finger movement, attitudinally described, is intentional, is not merely that the typist cannot give a full attitudinal description of it. The reason is that at the time of the action he cannot even say which finger he is using. It is true that, when he was learning to type, he did know which finger he used to type the letter $\mathrm{S}$, and so in those days his basic action, according to Goldman, was the finger movement, attitudinally described. But when he became proficient, the action which had been non-basic for him, typing the letter S, became basic for him. This is a common way of extending one's repertoire of basic actions, unlike the more commonly discussed way, which is the development of an ability to control some physiological process or event which was not previously under one's control even as a non-basic action. An example of this less common way of extending one's repertoire of basic actions would be acquiring the ability to send up one's bloodpressure. Or if it is thought that we can already perform this feat as a non-basic action, better example would be the one discussed by Danto - raising one's hat psycho-kinetically ${ }^{4}$.

It should also be noted that, when Goldman is forced to the conclusion that the experienced typist's basic action is typing the letter $\mathrm{S}$, he is not assuming that an agent who is doing $\mathrm{X}$ intentionally must know that he is doing $\mathrm{X}$. That assumption, interpreted in one way, is false. For to borrow a recent point of Davidson's, the typist might be making two carbon copies and making them intentionally, and yet he might not know that the second sheet of carbon-paper really was passing on the letters imprinted on the top sheet of white

4 A. Danto: "What we can do" Journal of Philosophy LX 1963. 
paper. Of course, this lack of knowledge is rare when $\mathrm{X}$ is a bodily movement attitudinally described, and the question is a gross one, such as the question whether one is moving the second finger of one's left hand, rather than a question about the finer details of the movement. But, though such examples are rare, they exist. A victim of a motor accident might not know to what extent his left arm had been paralyzed, and he might be unable to see his fingers. But Goldman's assumption about the connection between doing $\mathrm{X}$ intentionally and knowing that one is doing $X$ should not be interpreted in this way. We should take it that he is making the correct assumption that an agent who is engaged in doing $X$ intentionally must know that he is engaged in doing $X$. That is all that he needs to assume in order to be forced to the conclusion that the experienced typist's basic action is typing the letter $\mathrm{S}$.

Goldman does not welcome this conclusion, because he shares the intuition that basic actions ought to be bodily movements described purely attitudinally. He observes that in fact most of them are, and on this ground he includes in his theory of basic action the axiom that they all are, thus securing what he calls "a degree of neatness and uniformity that does not exist in the raw data. But such idealizations", he says, "are often useful in the construction of theories. Once the theory is clearly understood for the idealized conditions, the special assumptions can be relaxed". (p. 68).

The crack which Goldman is here papering over may be a symptom of serious trouble. So let us look into it.

The first thing that we see is something already mentioned. It is not quite accurate to say that the experienced typist does not move the second finger of his left hand intentionally. Certainly he does not move it with the specific intention of making a movement that satisfies that attitudinal description. But he does make it with the general intention of making whatever movement will lead to the typing of the letter S. So an accurate statement of Goldman's view about the connection between an action's being basic and its being intentional 
would go like this: An agent who does $X$ as a basic action must be doing $X$ with the specific intention of doing $X$ : it is not enough that he should be doing $X$ with the general intention of doing whatever will lead to $\mathrm{Y}$, where $\mathrm{Y}$ is a result that he specifically intends to bring about.

This tightening up of Goldman's view about the connection between an action's being basic and its being intentional is obviously necessary, and it may seem hardly worth formulating. But the distinction between general intention and specific intention can be applied to two other types of case, and this gives it greater importance.

First, we may apply it even further outside the vestibule of agency in the following type of case. Someone who buys a box of matches from a vending machine makes the invisible mechanism work with the general intention of making it work in whatever way will lead to the extrusion of a box of matches. But a maintenance man, who suspects a fault in the machine, will open it up and make the machine go through the same series of movements with the specific intention of making it go through those movements, itemized as " $\mathrm{A}$ ", " $B$ ", "C", etc., where these letters stand for specific descriptions known to him.

There are three distinct contrasts between the performances of these three agents. First, the purchaser is specifically interested only in the extrusion of the box of matches when he inserts his coin, but the maintenance man is also specifically interested in all the preceding causal links. Second, the purchaser cannot, but the maintenance man can, specify the preceding links. Third, the purchaser is in any case not in a position to check their occurrence, but the maintenance man does put himself in a position to check them by opening up the machine.

The other application of the distinction between general and specific intention is within the vestibule of agency. If I clench my left fist, there is a sense in which I send an impulse down the connecting motor nerve. However, as far as 
I know, nobody counts the sending of this impulse as a basic action. But why not? A plausible answer is that $I$ send the impulse only with the general intention of sending whatever impulse will lend to the clenching of my left fist. Here, of course, I need some general knowledge of the working of motor nerves and muscles. For if I had no such general knowledge, I could not send the impulse even with that general intention. Similarly, if the purchaser had no general knowledge of the working of vending machines, he could not even have the general intention that I ascribed to him.

This last application of the distinction between general and specific intention reveals the source of the trouble in Goldman's theory of basic action. For I take it as obvious that those, who follow Davidson ${ }^{5}$ in picking out a class of actions that are done intentionally under some description, mean that they are done with some specific intention. I think that it is also obvious that an action cannot be performed with a general intention unless it is also performed with a specific intention. For example, my clenching of my left fist cannot be done with the general intention of sending whatever impulse will lead to it without also being done with some specific intention, and the obvious candidate in this case is the specific intention of clenching my left fist. It follows that, if a Davidsonian action is done with a general intention, then it must also be done with another intention, and, if that intention too is general, there will be a regress which will continue until a specific intention is reached.

It may be objected that no intentions are really specific, because there is an element of generality in the formulation of every intention. This is an interesting point, but $I$ have no time to deal with it. All I can do now is to say that the intention to clench my left fist and the intention to elicit a box of matches from the vending machine are, for me, paradigm cases of specific intentions.

5 D. Davidson: "Agency" in Agent, Action \& Reason, papers give to the Fourth Philosophy Colloquium, University of Western Ontario, 1968; Toronto, 1971. 
We are now in a position to diagnose the source of the truths in the theories of basic action developed by Danto, Chisholm and Goldman. These theories are attempts to locate the basic action within every Davidsonian action. Given the view that all basic actions are done with specific intention, the basic action in any case will always be one of the actions which stops the regress of general intentions. But Danto's original insight was that, when the components of an action are distinct events related causally - A, $\alpha$, etc. - there is another potentially infinite regress: the agent cannot produce every component of an action by producing something else which causes it. Now there is a sense in which I do send an impulse down the motor nerve to my left hand. So if Danto were using the phrase "producing something else which causes it" in this sense, the two regresses would be stopped at the same point in this case. For the causal regress would come to an end with something that I did produce, though not with specific intention. However, Danto is evidently using the phrase to mean "producing some cause with the specific intention of producing that cause". This too ensures that the two regresses can be stopped at the same point in every case, but the point at which they will be stopped will not be the point picked out by the previous method. For we will now stop them both at the earliest cause that the agent produces with specific intention, and any prior cause would be the wrong kind to continue the regress. But at the same time this will remove any possibility of ensuring that the two regresses will always be stopped at a bodily movement described purely attitudinally. In fact the case of the experienced typist is one of many different kinds of counter-example to the thesis that they can always be stopped at such a point, and not a stray exception to the general run.

As I said, a plausible reason for not counting my sending of the impulse as my basic action is that I send it only with the general intention of sending whatever impulse will cause the clenching of my left fist. But we may prefer to adopt a 
slightly different explanation. We may say that my sending of the impulse cannot be instrumentally basic. This is what Annette Bain ${ }^{6}$ says, and Chisholm and Goldman say substantially the same thing in different words. This explanation entails the previous one, because an action can be instrumen. tally basic only if it is performable with specific intention.

But it also opens up another line of industry. For an action may be performable with specific intention without being instrumentally basic. For example, a physiologist might send down a particular nerve an impulse which he could specify, and which he wished to record on an ammeter, and yet he might find that the only way in which he could send it was by clenching his left fist with the specific intention of clenching it. This raises the question: What exactly does it mean to say of this agent that the only way in which he could send the requisite impulse was by clenching his left fist with the specific intention of clenching it?

One way to get an answer to this question is to contrast this case of the physiologist with a more extreme case. When we say that the physiologist has to clench his left fist in order to send the impulse, we mean more than that the clenching is an unavoidable result of sending the impulse. We mean that he regards the production of this result as an unavoidable means of sending the impulse in spite of the fact that the causation goes the other way. But, we may ask, why should he not regard the sending of the impulse as the instrumentally basic stage? After all, we are assuming that he has identified his various impulses as $\mathrm{A}, \mathrm{B}, \mathrm{C}$, etc. like the maintenance man, and that he has recorded them on his ammeter. So he is in a position to send this particular impulse with specific intention. Why then should he not regard it as instrumentally basic?

It is at this point that a more extreme example will provide a useful contrast. Of course, the physiologist could treat the

6 A. Bain: "The Search for Basic Actions" American Philosophical Quarterly, 1971. 
sending of the impulse as instrumentally basic. But in his case that would be an unnatural way of looking at the matter. However, we can imagine the case of a child, who is born with all his motor nerves severed at some point outside his cortex. A therapist then undertakes to teach him to perform minimal basic physical actions. So she connects up the broken ends of his motor nerves to dials which will record any impulses that he may send. These impulses are identified as A, B, C, etc., and when she calls out their names, like one of Wittgenstein's builders, he produces the one that she asks for, and he observes its effect on the connected dials, $\alpha, \beta$, $\gamma$, etc.

Even in this case the agent might regard the flickering of the dials as his instrumentally basic actions. For greater pressure of circumstances might be needed to get him to make the unnatural retreat into the vestibule of agency. So let us add a further feature to the example: let us suppose that the child is wired up to dials only for brief periods each day, during which he learns to send the various impulses, and that he continues to send them unmonitored when the panel of dials has been disconnected. This really does seem to be a case in which the agent would regard his production of ef. fects within his own nervous system as his instrumentally basic actions. If at some later date the gaps in his motor nerves were repaired by surgery, he would, at first, regard his own limbs as a set of tools.

So much for the connection between an action's being basic and its being intentional.

I now take up my second problem, about the general requirement that the causation of an intentional component of an action should follow an appropriate route. This was illustrated by the example of the gunman who gave his enemy a fatal 
heart-attack. The question was "Did he kill him intentionally?"

I shall approach this deviant case by way of a series of deviant cases which differ from it in various relevant ways. In order to give the discussion some structure, I shall set up a frame of reference by making three stipulations about an agent who does $\mathrm{A}$ intentionally.

(1) He must bring about A with the specific intention of bringing $\mathrm{A}$ about.

(2) If $\mathrm{A}$ is non-basic, he must bring it about by reliable stages.

(3) These stages must match their specifications in his plan.

The first stipulation applies whether A is basic or non-basic. The second and third apply only to cases in which A is non-basic. In the last section of this paper I shall inquire whether these last two stipulations should be generalized so that they will apply to the prior stages of basic actions too.

The first of the three stipulations is non-controversial. The second is vague, because it does not indicate what standard of reliability has to be met. But it has some initial plausibility, because an intentional action surely ought not to succeed by chance. The third stipulation may be too strict, because there may be cases in which it does not matter if the goal is achieved through prior stages which do not match their specifications in the agent's plan. But it too has initial plausibility, because, if the prior stages of a non-basic action are reliable, that ought to be an achievement of art rather than of nature. For they are not the prior stages of the basic action contained within the non-basic action. Those prior stages might be left to nature. But these prior stages consist of the basic action itself and the stages intermediate between it and the achievement of the goal. Naturally, such prior stages will not all be specified in the agent's plan. The point of the 
third stipulation is that, when they have specifications in his plan, they must match them.

We may introduce a second-order concept of reliability at this point. We may say that a performance is secondarily reliable if its prior stages match their specifications in the agent's plan. Here secondary reliability is contrasted with primary reliability. A performance is primarily reliable if the goal is achieved by dependable stages. The second stipulation requieres that non-basic intentional performances be primarily reliable, and the third stipulation requires that they be secondarily reliable. A performance may have either type of reliability without the other.

The way to evaluate these stipulations is not by general argument, but by testing them on deviant cases. This I shall now do.

The first stipulation is, as I said, non-controversial. If the gunman's specific intention had been to shoot a deer, and if he did not know that his enemy was in the line of fire, then, as Aristotle says, he would not have killed him intentionally, however pleased he was with the result.

The second stipulation was that, if $A$ is non-basic, the agent must bring it about by reliable stages. In order to test the general validity of this stipulation, we need a case in which the prior stages match their specifications in the agent's plan, but the achievement of the goal is very lucky. So let us suppose that the gunman's enemy has taken cover behind a rock in a gully, and he fires with the specific intention of hitting him with a ricochet. The bullet does ricochet off the wall of the gully very luckily into his victim's heart. Did he kill him intentionally?

I think that the answer to this question is that he did kill him intentionally, but that this answer needs to be qualified. We ought to qualify it by adding that the shot was a very lucky one. Equally, if he himself had been asked before he fired whether he intended to kill his victim by a ricochet, it would have been necesarry for him to qualify his statement 
of that intention by adding that, at least, that is what he hoped to do.

I do not want to draw a strong conclusion from this example. But what it does show is that, when the prior stages are very unreliable, then, even if they match their specifications in the agent's plan, it is too much to say that the agent achieved his goal intentionally (period). Some qualification is needed, because in a standard case of non-basic intentional action the prior stages will, at least, be more reliable than they are in this case. It is, of course, a further question how exactly the necessity for qualification is to be explained within a general theory of meaning. But I shall rest on the fact of its necessity without seeking an explanation of it.

The third stipulation was that the prior stages must match their specifications in the agent's plan. In order to test the general validity of this stipulation, we need a case in which the prior stages lead reliably to the achievement of the goal, but some of them do not match their specifications. In the terminology introduced just now, we need a performance that is primarily reliable but not secondarily reliable.

In fact, there are two types of case which exemplify this pattern. First, the basic action may fail to match its specification, but this error may be cancelled by the mismatch of a later stage in the performance in such a way that the stages, taken together, reliably lead to the achievement of the goal. For example, the gunman intending to point his rifle at his enemy may in fact aim off to the left, but a cross wind blowing from the left may cause the bullet to fly on a curved path, which was not intended, into his victim's heart, which was intended. In that case did he kill intentionally?

It is clear that his performance is not a complete success (Chisholm's felicitous phrase). ${ }^{7}$ For two of its stages fail to match their specifications. But this turns out to be fortunate. For given the second mismatch, if the first one had been a match, the bullet would have passed harmlessly to the right

7 Loc. cit., p. 210. 
of the target, and, given the first mismatch, if the second one had been a match, the bullet would have passed harmlessly to the left. But as it turns out, the second mismatch cancels the effect of the first and the goal is achieved by reliable stages. But how does this affect the question whether the gunman killed his victim intentionally? I think that the answer is the same as it was in the previous case, but for a different reason. We surely ought to qualify the statement that he killed him intentionally by adding that he was lucky. But the qualification would be needed not because the performance was primarily unreliable, but because it was secondarily unreliable. In general, when an action is non-basic, match is the only reliable way of getting a reliable sequence consisting of a basic action and ensuing intermediate stages. In this area we cannot depend on nature to make good any deficiencies of art.

In order to get an example of the second type of case, I need to change guns. A field gun fires a shell which drifts to the right and so always flies on a curved path like the exceptional path of the bullet in the last example. Naturally, the gunsight compensates for this drift. But a gunner who did not know about it would suppose that, when he sighted his gun, he was pointing it straight at his target, and that, when he fired it, he was sending the shell on a straight path. Thus two stages in his performance would fail to match their specifications in his plan. The difference between this case and the previous one is that the gunner's basic action is not one of the two mismatching stages. The similarity with the previous case is that the second mismatch cancels the effect of the first in such a way that the goal is achieved by reliable stages.

In this case we would say without qualification that the gunner hit his target intentionally. Of course, he did not understand the ballistics of his achievement, and, if he were asked about the two intermediate stages, he would give an erroneous account of them. But his errors would be merely 
theoretical in relation to the task of firing the gun with the help of the gunsight. For both the mismatching stages lay beyond his basic action. It is true that his performance suffered from the general fault of secondary unreliability. But secondary unreliability in the intermediate stages produces no ill effects in practice if the whole sequence of stages leads dependably to the achievement of the goal, as it does in this case. It would cause trouble only if the agent on another occasion had to initiate the action at the first of the two mismatching stages. In this example, it would cause the gunner to miss the target if he lost his gunsight and so was forced to shoot by aligning the barrel of the gun by eye.

So far, I have examined performances exhibiting primary without secondary unreliability, and performances exhibiting secondary without primary unreliability. Suppose now that we have a performance which combines both faults. The original example of the gunman who caused his victim's death by heart-attack was such a case. For the actual causation of the death included two mismatching stages and it was completely unreliable. In this case we are in real doubt whether to qualify the statement that he killed him intentionally or to deny it outright.

So much for the problem about the appropriate causation of non-basic intentional actions.

\section{III}

I now want to look at the same problem in the special form that it takes for basic intentional actions. For my main interest is in the intersection of the two problems discussed so far, one concerned with the appropriate causation of intentional actions, and the other concerned with the connection between an action's being basic and its being intentional. I shall move into this area by way of a criticism of something

8 Loc. cit., p. 62. 
that Goldman says. According to him, ${ }^{8}$ desires and beliefs do cause basic actions (which, in his view, are always done with specific intention), and they must cause them in the appropriate way; but he maintains that the question, what the appropriate way is, is a question for scientists and not for philosophers.

If this meant only that the question of fact must be settled empirically, it would be non-controversial. But it has two further implications. First, it implies that the empirical inquiry is entirely technical. Second, it implies that its results are irrelevant to the concept of an intentional basic action. I would reject both these elements in Goldman's thesis, particularly the second. The second element is really a kind of psychological feudalism, which treats the psychological connections in this area as dominant. Although it allows that some physiological infrastructure is needed, it treats the nature and work of the actual serfs as wholly irrelevant to life at the top.

I might try to prove that this view is mistaken by appealing to one of the examples given at the beginning of this paper. I might argue that the case of the nervous servant proves that we can sometimes recognize a particular causal route as one that is inappropriate for an intentional basic action. Incidentally, in this case our judgement would be based on non-technical knowledge.

But there would be a difficulty in developing this argument. It would be objected that in this case the agent knew that he did not perform an intentional basic action. So though it is true that the constellation of desire and belief caused the action in a recognizably inappropriate way, it might be maintained that there is no need to include this fact in the analysis of the statement that he did not relax his grip intentionally. We can rely instead on the psychological fact that the agent knew that this was not an intentional basic action. That is the distinctive mark of such cases.

This objection tries to exploit an important difference be- 
tween this case and the cases of questionably intentional nonbasic actions discussed in Part II of this paper. For in those cases the question was not whether the agent performed his basic action with the specific intention of performing it. The question was whether he achieved his non-basic goal intentionally. Now that question could not be answered from the available psychological resources. It was found necessary to bring in the two concepts of reliability and so to bring in the causation of the achievement. But, it is now being suggested, when the question is whether a basic action is performed intentionally, we can answer it without going outside the psychological facts.

There are two ways of dealing with this objection. I could side-step it by citing other examples in which the appeal to causation would be more obviously necessary, or I could keep to this example and show that it too necessitates the appeal to causation, less obviously but no less surely. I shall use both strategies.

First, consider the suggestion that the agent knows when he performs an intentional basic action, and so there is no need to include any requirement of appropriate causation in the analysis of what he knows. This is evidently a non sequitur. For the first distinctive mark of intentional basic actions that springs to mind may not be the only one, and, if there are others, they may have as good a title to be included in the analysis of the concept. This argument could be reinforced by changing the example slightly: we could suppose that the servant was genuinely uncertain how much was attributable to his trembling, and how much to his agency.

There is in any case a fatal incoherence in the suggestion that the agent's knowledge is enough. For, as Butler observed, "knowledge presupposes truth, and cannot, therefore, constitute it". Now it is not possible to evade this stricture by arguing that the agent's knowledge in this case has a distinctive character. The argument would have to be that the agent in the example knows that it is his trembling that is relaxing 
his grip, because, if he were relaxing it, he would know immediately that he was doing so. But this will not circumvent Butler. For the explanation of the agent's knowledge, that he did not relax his grip intentionally, must include the crucial fact that, if he did have immediate knowledge of his own agency, it would be a distinctive type of immediate knowledge. For example, if the servant had dropped the vase intentionally, his knowledge that the relaxation of this grip was occurring would not have been based entirely on sensory feedback: it would also have been based on his knowledge that he was making it occur. But this specifies the distinctive character of his immediate knowledge by bringing in the concept of agency again. Now this circle does prevent the agent from using this distinctive type of immediate knowledge as a criterion of intentional basic action. But it does prevent a philosopher from terminating the analysis of the concept at this point. For the philosopher must specify the distinctive type of immediate knowledge in a non-circular way. Therefore, if the analysis is going to scape Butler's stricture, it must contain something more.

The second way of dealing with the objection is to cite other examples in which it is more obviously necessary to add a causal requirement to the analysis of intentional basic action.

Suppose that the gunman is just about to squeeze the trigger, but the motor nerve to the index finger of his right hand has been severed by an accident in the chase and he is unaware of this fact. However, at the very moment of intended action, a nearby flash of lightning sends an induced current down the motor nerve from the point of severance to the index finger, and the intended movement is made. In this case it is clear that he does not perform an intentional basic action, in spite of the following three facts: first, the movement is exactly as he intented it; second, he himself would claim to know that he had made it intentionally; and third, his claim 
to knowledge would be of the distinctive immediate type that the objector tried to exploit.

In this example the causation does not start from the agent's constellation of desire and belief and then follow an inappropriate route. It starts from the lightning, which is an inappropriate originating cause. But the example does demolish the suggestion that the analysis of the concept of intentional basic action is complete after we have included the requirement of distinctive agent's knowledge and before we have included any requirement about causation.

However, that is not quite the point that I said that I would establish. I said that I would show that Goldman is wrong when he maintains not that the appropriateness of the cause, but that the appropriateness of the causal route is a non-philosophical problem. But in order to make this point, I need cases like that of the nervous servant, where the cause is appropriate, but its operation too devious. I also ought to build up a positive account of the causation of intentional basic actions, instead of merely criticizing psychological feudalism, and, in order, to carry out this task, I shall have to make use of conclusions reached in the first two parts of this paper.

Let me start with a point taken from the discussion of nonbasic intentional action. In a standard case of that kind the sequence of intermediate stages has to possess some degree of reliability. But what was wrong in the latest version of the story about the gunman was that the impulse produced by the lightning was a pure coincidence. The agent did not cause the bodily movement in any way at all, and so there was no performance to qualify as primarily reliable. This is a limiting case. We can move inwards from it in the direction of the normal case by supposing that the impulse sent out from the agent's cortex itself attracts the lightning, which in its turn generates the impulse in the motor nerve beyond the point of severance. In that case the agent would cause the movement of his trigger finger, but his performance would entire- 
ly lack primary reliability. So there would be a strong case against the verdict that he moved his finger intentionally.

This example is quite like, but not entirely like that of the nervous servant. The difference is that the gunman might think that he performed the basic action intentionally, but the servant, as originally described, did not make that mistake. If we want a parallel case in the area of non-basic action, we have the case in which the gunman causes his victim's death by a heart attack. That performance as we saw, possessed neither primary nor secondary reliability, and I concluded that we would be in real doubt whether to deny or merely qualify the statmeent that he killed his victim in. tentionally. But is it so clear that the same verdict should be given in this case, in which an intended basic movement is caused by the agent's producing it, as he thinks, intentional. ly? I must admit that this is not yet clear, and the obscurity is partly attributable to the fact that nothing has yet been said about the secondary reliability of basic performances.

How, if at all, does the concept of secondary reliability apply to a basic performance? A performance has secondary reliability if and only if all its stages match their specifications in the agent's plan. But this concept gets no grip on the prior stages of a basic action. For, to use a point made earlier, when a marksman moves his trigger finger, he does not send the impulse that makes it move with the specific intention of sending that impulse. He sends it only with the general intention of sending whatever impulse will cause the movement, and he cannot even have this general intention unless he has the requisite general knowledge of the working of motor nerves and muscles.

But when he does have the general knowledge, and so can have the general intention, it is possible for the actual causation of the basic action to match or not to match the general intention. Naturally, we cannot say that the prior stages of the basic action may match or fail to match their specifications in the agent's plan. For they are not specified in his 
plan. All that we can say is that they may match or fail to match the agent's general intention, and that his performance has secondary reliability when and only when they do match it.

If this is a concept of secondary reliability, it is a different one. Instead of being based directly on specifications of the different stages in the agent's plan, it is based on a general instruction to bring about whatever stages will lead to the achievement of the goal. This generality is inevitable in the obscure part of the vestibule of agency. Its effect is to transform the concept of secondary reliability that we use in this area into a derivative concept. For the application of the concept to basic performances, instead of depending on stepwise match between each prior stage and its specification, depends on global match between the whole sequence of prior stages and the recipe, "Whatever stages will cause the intended movement". If this is a plan, it is one that does not involve any thought.

It may be objected that this transformation of the concept of secondary reliability in the vestibule of agency effective. ly reduces it to primary reliability. For the general recipe, "Whatever stages will cause the intended movement", presumably means "Whatever stages will cause it in a reliable way". Thus it is a recipe which would be followed in a normal case of marksmanship, but which was not followed in the cases in which lightning intervened. But if this is what the recipe means, secondary reliability will add very little to primary reliability in this area. For the only addition that it will make is the requirement that the agent intend the prior stages of his basic action to be reliable. But that almost goes without saying.

This objection would be substantially correct, if the recipe really did mean no more than "Whatever stages will cause the intended movement in a reliable way". But it would not be entirely correct even on this very general interpretation of the recipe. For it is an important fact that the agent does 
intend the prior stages of his basic action to be reliable, even if it does go without saying. In any case, it is doubtful if this interpretation of the recipe is the right one. There is case for a more restrictive formulation of the agent's general inten: tion.

In the remainder of this paper I shall argue for these points. First, I shall argue that, when the recipe is interpreted in the suggested very general way, the secondary reliability of a performance does almost collapse into its primary reliability, but that it does not quite collapse into it, and that the reason for this is important. Then I shall argue for a more restrictive formulation of the agents' general intention.

First, consider the suggested collapse of the secondary reliability of a basic performance into its primary reliability. We can imagine cases like that of the physiologist described earlier, who clenched his left fist in order to send a specific impulse down the motor nerve. This agent would be like a gunner who used the gun-sight to train his gun onto a certain target in order to get the gun-barrel pointing in a particular direction. Each of these two agents would succeed in bringing about the intermediate stage which was his goal only if he held a correct theory about the causation of the ultimate stage which was his means. On the other hand, in each case, if the goal was the ultimate stage, it would make no practical difference if the theory about the intermediate stake was incorrect. However, if the physiologist decided to clench his left fist by using an electrode to produce the impulse artificially, he would fail if his theory was incorrect. Similarly, if the gunner lost his gun-sight and decided to shoot at a target by aligning the gun-barrel by eye, he would fail if he did not know that shells drift to the right. Thus an error which begins by being merely theoretical may have practical consequences when the agent tries to manipulate a stage which had previously been left to take care of itself.

But most of the cases in which the prior stakes of ordinary basic actions are brought about with specific intention are 
imaginary cases. In real life, they are nearly always brought about only with some general intention. So if the general intention were to achieve the goal through any reliable sequence of stages, as the objector claims, then the secondary reliability of a basic performance really would almost collapse into its primary reliability.

However, it still would not quite collapse into its primary reliability. For though the content of the agent's general intention would only be that the goal should be achieved by some reliable stages, it would still make a difference that the agent did have this general intention. Not only do we require that the prior stages should be reliable, but also he intends that they should be reliable. A rational agent, unlike an animal, cannot fail to be concerned with what happens in the vestibule of agency.

The argument for this point starts from a conclusion drawn earlier in this paper. I concluded that, if the prior stages of a non-basic action have no reliability whatsoever, then we need to qualify the statement that the agent performed it intentionally. I could have added that an agent must intend his own intentional action to be at least nearer to the standard case: i.e. he must intend that his basic action should bring about his goal by stages which have some degree of reliability. Now this principle evidently ought to be extended to cover the prior stages of basic actions. Therefore an agent must intend that those prior stages be reliable, even when he cannot specify them.

So far, I have been conceding that, when an action is ba. sic, the agent's general intention should be formulated as the objector formulated it: the agent intends to bring about whatever prior stages will cause the intended movement in a reliable way. I now want to revoke the concession, because this formulation seems to be too general, and I shall argue for a more restrictive one. If my argument is accepted, the objector's main point will still be left intact. For his main point was that the agent's general intention is derivative from cer- 
tain facts which he is usually unable to specify. If I am right, those facts will not be quite what the objector said that they are. But he will be right in maintaining that the agent's general intention is dependent and recessive in the normal case. It could become independent and dominant only by becoming specific and instrumental, as happened in the case of the child described in Part I of this paper.

What restriction should be put on the formulation of the agent's general intention about the prior stages of his basic action? The discussion of this question may be divided into two parts. First, we may go right back to the source of the action and examine a causal link about which I have said nothing so far. Second, we may take a closer look at later causal links, such as impulses in motor nerves and contractions of muscles.

The first important causal link between the constellation of desire and belief and the bodily movement is the neural event within the cortex which intiates the impulse in the motor nerve. If the bodily movement is intentional - or, perhaps, if it is consciously intentional (in order to allow for, and exclude Freudian cases) - this causal link is essential. For the desire and belief may be present without any intention to produce the bodily movement, and, even when the intention has been formed and the causation does operate, it must go through this link. If it did not, the agent would not know in the distinctive, immediate way described earlier that he was making the movement. Of course, when he has this knowledge, it is not based on the occurrence of this link. It is immediate knowledge and so it is not based on anything. But it may be caused by something, and it evidently is caused by the event within the cortex that initiates the impulse. It is not infallible knowledge.

We may ask about this essential link the three questions that $I$ asked earlier about the impulse in the motor nerve. Is it normally brought about by the agent with specific in- 
tention? Can he bring it about with specific intention? And can it be his instrumentally basic action?

These are important questions, because this initiating event, viewed psychologically, is what many philosophers have called "an act of will". Viewed in this way, it has always seemed curiously diaphanous and even mythical, and it appears to lead inevitably to a familiar infinite regress of prior actions. So it is worth looking at its neural aspect, in order to see if we can make the intuitively attractive concept of "an act of will" theoretically acceptable.

The answer to the first of the three questions is not quite the same as the answer to the same question about the impulse in the motor nerve. The impulse has no psychological aspect, and so it could be produced with specific intention only under its physiological description. But the agent does not normally know its physiological description, and so he is not normally in a position to send it with specific intention. But the initiating event in the cortex does have a psychological aspect. It is the act of will to make that particular movement. This description is always known to the agent. So he can always produce the initiating event with specific intention under its psychological description, just as the physiologist described earlier sent the impulse with specific intention under its physiological description. In both cases the cause is produced by producing its effect, and so there is no basis for the argument that the cause must be produced by performing a prior action which causes it. This demolishes the familiar argument that acts of will lead to an infinite regress.

However, it is difficult to detect any difference between an agent who clenches his left fist with that specific intention and an agent who clenches it with the specific intention of producing the requisite act of will. But the explanation of the difficulty is simply that the act of will is described psychologically entirely through its content, and, when it is described in that way, it is inevitably diaphanous. 
But it would be a mistake to conclude that it is mythical. For when the act of will is described physiologically it immediately loses its diaphanousness. Of course, the agent cannot normally describe it physiologically, and so - to complete the answer to the second question - he cannot normally produce it with specific intention under its physiological description. But a physiologist might be able to do both these things. He might want to record the occurrence of the cortical event on an encephalograph. Nobody would regard this event as mythical.

He could even produce it by artificial stimulation of his own cortex, thus putting it into causally non-basic position in the sequence of events constituting his action. When this is done to the agent by someone else, he is, and feels that he is, the originator of an intentional action, even though he may know that, in a sense, the experimenter is its originator. The description of this experiment naturally puts a great strain on such a conservative concept.

But could anyone produce the initiating event in his own cortex as an instrumentally basic action? I do not see why not. We can modify the earlier account of the child born with all his motor nerves severed somewhere outside his cortex. We can suppose that they are severed at the limit of his cortex, and that everything then happens as described in the original account of the case. This child really would produce the cortical initiating events as his instrumentally basic actions.

So much for the initiating event, which, far from being mythical, is an essential causal link between the constellation of desire and belief and the intentional bodily movement. This puts a restriction on the formulation of the agent's general intention. We cannot say, as the objector did, that his general intention is to produce any sequence of prior stages that will lead to the bodily movement. We must require that one of the stages be the initiating event and that it have a psychological aspect. If this requirement is not met, he will 
not have made the bodily movement with conscious intention even though he may have a suitable constellation of desire and belief.

Finally, let us take a closer look at the later causal links. Must some restriction be put on the formulation of the agent's general intention in this area too? Or will any reliable sequence of stages after the initiating event suffice for an intentional basic action?

The first thing that needs to be done here is to relax the requirement of reliability. If the motor nerves to my left hand were almost gone, I would seldom succeed in clenching it. But when I did clench it, I would be doing so intentionally. Such examples could be multiplied. They show that it is too much to require that the prior stages of a basic action should be reliable. All that we ought to require is that they should belong to a reliable type of sequence.

But will any reliable type of sequence suffice? I think not. For suppose that we have a case like that of the gunman and the lightning, except that the substitute causal link, unlike the lightning, is part of a reliable sequence. For example, a physiologist always observes the impulse in a patient's motor nerve, and always reproduces it artificially beyond the point of severance. In such a case the agent's movement of his right index finger would not be his intentional basic action, in spite of the fact that its causation started from the essential initiating event, and that it was reliable.

One reason that might be given for this verdict is that the intermediate stages are not the normal ones for a human agent. But this cannot be quite the right reason. For we would allow that it was a basic intentional action if the gap in his motor nerve were bridged by a prosthetic device. Such a device would be an action-aid in the sense in which people now have hearing-aids. But the physiologist and his apparatus could not be regarded as the patient's actions-aids, because the apparatus was not regularly attached to his body and its successful operation required the physiologist's agency. 
In the original case of the broken vase the servant's nervousness could not be regarded as an action-aid. But the reason why it could not be so regarded was different. It was that nervousness is not a reliable type of link in the sequence of stages leading to the relaxation of grip. Of course, that was not the only bar to regarding the relaxation as an intentional basic action. For the essential initiating event in the cortex was also lacking. But it was one of the bars. Incidentally it would be possible to imagine another kind of case in which his nervousness increased the flow of adrenalin and so functioned as an entirely different kind of action-aid - not as an artificially substituted link, but, rather, as an auxiliary to the normal mechanism. However, that was not the case originally described.

It seems, then, that the objector's formulation of the agent's general intention needs to be corrected in three different ways. First, the agent must intend to bring about the bodily movement through the essential initiating event. Second, he must intend that the sequence of intermediate stages that follow that event should belong to a reliable type. Third, this reliable type of sequence must be specified in his intention as either the normal type for human agents or else a variation produced by a prosthetic device which is, in some sense, part of himself and operated by himself alone.

The reason why the agent's general intention has to be formulated in this way is a variant of the reason given earlier. These clauses specify the necessary conditions of intentional basic actions, and he intends to perform an intentional basic action.

Nevertheless, the objector's main point is roughly correct. The secondary reliability of a basic performance does almost collapse into something that involves the reliability of the type of sequence that its stages exemplify. This point could be developed further. If we are looking in the vestibule of agency for the closest analogy to secondary reliability 
outside the vestibule, the best candidate might well be something other than the match between the actual sequence of stages and the agent's general intention. For his general intention does little to secure this match, and, if we ask what does secure it, the answer seems to be mutation and natural selection. 
En el artículo se examina la intersección de dos problemas.

(1) Dado que las acciones intencionales son causadas por deseos y creencias, ¿hay un modo especial en que tengan que ser causadas?

(2) ¿tienen que ser intencionales las acciones básicas?

Se desea averiguar si la ruta causal de las acciones básicas es restringida y se parte de estos problemas, los cuales se ilustran mediante ejemplos: (1) un pistolero desea matar a otro, le dispara y falla, pero el ruido le produce un ataque mortal al corazón. (2) un taquimecanógrafo experimentado $-T$ - imprime la letra ' $S$ ' con el segundo dedo de la mano izquierda. ¿Es la acción básica imprimir 'S' o mover el dedo? Si es la primera descripción, se refiere a algo exterior al agente - la máquina-, lo cual va contra la idea de acción básica. Si es la segunda descripción, puede no ser intencional en el caso de no saber qué dedo estaba usando, lo cual contradice las teorías existentes de que toda acción básica es intencional.

La intersección de los dos problemas se ilustra con el ejemplo de un sirviente que desea romper un jarrón, se pone nervioso y su nerviosismo hace que se le caiga. Parecería que la acción no fue intencional porque la ruta causal fue inapropiada.

No se discute si es que una acción intencional tiene que ser causada apropiadamente por deseos y creencias, se supone sólo que hay un elemento causal importante en el análisis de "acción intencional". Se justifica la necesidad de introducir el problema de la acción básica porque se ocupará del "vestíbulo de la acción". En la acción exterior la causación inapropiada se muestra como discordancia entre lo que sucede y la intención. En la acción "dentro del vestíbulo" se muestra de otra forma porque la descripción del movimiento corporal en términos de actitud no incluye la especificación de la ruta causal.

I. ¿Cómo se conecta el que una acción sea básica con el que sea intencional? Goldman afirma que toda $a b^{*}$ es intencional, concluyendo que la ab de $T$ es imprimir ' $\mathrm{S}$ ' y asumiendo que un agente hace $\mathrm{X}$ intencionalmente sólo si sabe que está involucrado en hacer $\mathrm{X}$. No está, empero, satisfecho con la conclusión, porque intuitivamente las ab son movimientos corporales descritos en términos puramente de actitudes.

Considerando la cuestión a fondo, se puede decir que $T$ no mueve

* En adelante usamos 'ab' en lugar de 'acción básica'. 
el dedo con la intención especifica de hacer el movimiento corporal, pero sí que tiene la intención general de hacer cualquier movimiento que lleve a imprimir la letra ' $\mathrm{S}$ '. Esta distinción entre intención específica y general la cual, según el autor, es muy importante, se puede aplicar a muchos casos y revela el origen del problema de Goldman.

Para el autor es obvio que hacer una acción intencionalmente bajo alguna descripción, significa que se hace con intención específica y que una acción no puede ejecutarse con intención genérica si no existe en algún punto una intención específica. Lo importante es que el regreso para encontrar la acción hecha con intención específica no se detiene siempre en el movimiento corporal (caso de $T$ ).

II. Respecto al problema (1) se analizan varios casos dentro del siguiente marco de referencia: para que un agente haga $A$ intencionalmente, se requiere: $i)$ que produzca $A$ con intención específica, ii) Si A no es una ab, debe producirla por etapas confiables, iii) que las etapas correspondan con las especificaciones de su plan. i) no es discutible, $i i)$ es vago, pero elimina el azar y $i i i)$ se refiere a la ab y las etapas siguientes, si es que están especificadas.

Se detallan los requisitos y se evalúan poniéndolos a prueba con casos divergentes y distinguiendo además, confiabilidad primaria $-\mathrm{C}_{1}$ - en la que el objetivo se alcanza por etapas confiables, de confiabilidad secundaria $-\mathrm{C}_{2}-$ en la cual es necesario que las etapas previas correspondan al plan. $\mathrm{C}_{1}$ y $\mathrm{C}_{2}$ son independientes. $\mathrm{Si}$ se da $\mathrm{C}_{2}$ pero no $\mathrm{C}_{1}$ y la acción alcanza su objetivo, decimos que es intencional aunque calificada como afortunada. Si se da $C_{1}$ pero no $C_{2}$ y el error en la ab se cancela con otro error en una etapa posterior, la acción es intencional y afortunada, pero por carecer de $\mathrm{C}_{2}$. En cambio si se da $C_{1}$ y no $C_{2}$, pero los errores no están en la ab, la acción es intencional sin calificación. Una ejecución en que falta $C_{1}$ y $C_{2}$ (ejemplo (1) ), nos deja en duda acerca de la intencionalidad.

III. Con relación a la causación apropiada de las ab, se critica la tesis de Goldman. Según ella los deseos y creencias causan las ab (hechas siempre con intención específica) y tienen que ser causadas de manera apropiada; pero considera que la cuestión de la ruta apropiada es una cuestión científica y no filosófica. Esto último implica que la investigación empírica es puramente técnica y que sus resultados son irrelevantes para el concepto de ab intencional. Se rechazan ambas implicaciones. En el caso del sirviente nervioso la ab no fue intencional porque la ruta causal fue inapropiada y para saberlo no hace falta conocimiento técnico. Tampoco es suficiente que el agente sepa que no es intencional. No bastan los hechos psicológicos $y$, con otros ejemplos en los que se cree que se hace una ab inten- 
cional pero la ruta es desviada por originarse la ab en una fuente externa, se prueba que la propiedad de la vía causal es un problema filosófico.

$\mathrm{C}_{1}$ y $\mathrm{C}_{2}$ se aplican también a las ab, pero respecto a $\mathrm{C}_{2}$ hay que observar que el agente no especifica las diferentes etapas de su plan. Tiene una intención general pero no específica de enviar determinados impulsos nerviosos, esto es, sólo de enviar cualquier tipo de impulsos que causen el movimiento. Aquí $\mathrm{C}_{2}$ es una correspon. dencia global.

Se plantea la siguiente objeción: si de este modo $C_{2}$ se transformó en $\mathrm{C}_{1}$, entonces 'cualquier etapa que cause el movimiento intentado' significa sólo 'cualquier etapa que lo cause de modo confiable'. Aun así hay una diferencia importante porque el primer enunciado alude a la existencia de una intención general por parte del agente. No basta la confiabilidad de las etapas, es necesario que se intente que lo sean aunque no se especifiquen.

Se propone otra formulación más restringida. En las etapas previas de la ab hay que examinar la cadena causal. El primer eslabón importante es el evento neurológico inicial, el cual es condición esencial de la intencionalidad. Acerca de esto se formulan tres preguntas $i)$ ¿Se produce normalmente con intención específica? ii) ¿Es posible producirlo así? iii) ¿Es la ab instrumental? En respuesta a $i$ ), este evento es el llamado 'acto de voluntad' visto psicológicamente -no fisiológicamente- y se produce con intención específica. La causa se produce mediante la producción de sus efectos y no conduce al famoso 'regreso al infinito' En respuesta a ii), normalmente, por ignorancia, no se puede producir intencionalmente bajo una descripción fisiológica. Con un ejemplo se responde afirmativamente a la pregunta iii). Si se acepta esto, la intención gene. ral no puede ser la de producir cualquier secuencia de etapas previas, una de ellas tiene que ser este evento, o de lo contrario no hay intención consciente.

En lo que se refiere a eslabones causales posteriores lo único que se exige es que pertenezcan a un tipo confiable de secuencia y que sean normales para un agente humano, o producidos por instrumentos que sean parte suya. Esta fórmula especifica las condiciones necesarias para una ab intencional.

La objeción es, empero, correcta en términos generales. $\mathrm{La}_{\mathrm{C}_{2}}$ in. terna es diferente a la $\mathrm{C}_{2}$ externa, porque en aquélla lo que asegura la correspondencia entre la secuencia real y la intención general es la mutación y la selección natural y no la intención general.

Resumen por Javier Esquivel 